\title{
PHILOSOPHICAL BACKGROUND OF THE CONDICTIO CLAIMS IN CLASSICAL ROMAN LAW
}

In this article the author analyses the problem of the philosophical background of the condictio claims in classical Roman law from three different aspects. First he deals with the issue of the apparent origins of the philosophical principles and concepts associated with condictio claims in sources such as ius naturale, aequitas, natura, etc. After dismissing the possibility of their postclassical origin, the focus of the analysis shifts to the possible influences of certain Greek philosophical schools on them, namely the Peripatetics and the Stoics. Finally, the actual reach of such influence is discussed.

Keywords: condictio, unjustified enrichment, ius naturale, aequitas, Roman law

\section{INTRODUCTION **}

Various instances of the use of condictio claims in different periods of Roman law and in correspondingly different procedural arrangements may be said to have had a generally very important role in the Roman law of obligations. For example, the condictio claims were used to reclaim a payment of indebitum (nondebt), payment of a sum given over in expectation of an event that eventually

* Henrik-Riko Held, Ph. D., Assistant Professor, Faculty of Law, University of Zagreb, Trg Republike Hrvatske 14, Zagreb; hheld@pravo.hr;

ORCID ID: orcid.org/0000-0002-6217-2655

** This paper is a result of a scientific project of the Faculty of Law, University of Zagreb, titled The New Croatian Legal System for 2018. 
did not occur, payment of a sum on a legal basis that later ceased to exist, etc. ${ }^{1}$ Therefore, it could be said that condictio claims were a sort of remedy for certain pecuniary imbalances that occurred in practice. For that reason, they are often associated with philosophical concepts and principles such as justice, equity, natural law, good faith, etc. in the sources, as it will be shown in the following analysis. $^{2}$

Taking those concepts and principles into consideration, the aim of this paper is to try to clarify whether any actual philosophical thought inspired Roman law in the pre-classical and classical periods in regard to condictio claims, and if it did, in what way and in what measure. Besides having academic relevance, this issue bears importance given that the classical condictio claims were the basis for the Justinianic system of the condictiones, which in turn was subject of the medieval treatment of the matter and later reception of Roman law in Europe.

In order to analyse this problem thoroughly, three different aspects of the issue should be dealt with. Firstly, the long-standing problem of the alleged postclassical interpolations of the concepts and principles associated with condictio claims, the matter that traditionally drew the most attention, should be revisited. Secondly, when the most likely timeframe of the origins of those concepts and principles is established, the next matter to be dealt with is the issue of the ostensible philosophical school that played the most important part therein. After that, it is discussed to which extent the pertinent philosophical school may have directly affected condictio claims in pre-classical and classical Roman law. With such a three-tier approach, we hope to contribute to a more thorough understanding of the condictio claims both in Roman law and in their later iterations throughout history.

1 On the matter in general, with detailed references to the sources and relevant literature, see Kaser, M., Das römische Privatrecht I (das altrömische, das vorklassische und klassische Recht), München, 1971, pp. 592 sqq.; Kaser, M., Das römische Privatrecht II (die nachklassischen Entwicklungen), München, 1975, pp. 421 sqq.; Zimmerman, R., The Law of Obligations. Roman Foundations of the Civilian Tradition, Cape Town, 1992, pp. 834 sqq.

2 Similarly, contemporary legal systems, in fields that may be associated with condictio claims (for example, unjustified enrichment), generally also acknowledge this philosophical and dogmatic aspect of the matter. For an analysis regarding the dogmatic aspects of unjustified enrichment in Germany (ungerechtfertigte Bereicherung) see Gödicke, P., Bereicherungsrecht und Dogmatik, Berlin, 2002. For an overview of a number of relevant issues in this regard in common law jurisdictions, see Chambers, R. et al. (eds.), Philosophical Foundations of the Law of Unjust Enrichment, Oxford, 2009. For Croatian literature on the matter see Klarić, P.; Vedriš, M., Građansko pravo, Zagreb, 2006, p. 644 and Vojković, L., Kondikcijski tužbeni zahtjevi (unpublished thesis), Split, 1997, pp. 22 sqq. 


\section{THE PROBLEM OF THE ORIGINS OF THE PRINCIPLES ASSOCIATED WITH CONDICTIO CLAIMS - A POSTCLASSICAL INTERPOLATION?}

Fragments from Justinian's Digesta dealing with condictio claims contain numerous references to concepts and principles such as justice, equity, natural law, etc. In one of the most famous fragments in that regard, attributed to the famous $2^{\text {nd }}$ century jurist Pomponius ${ }^{3}$, D. $12,6,14$ (Pomp. 21 ad sab.), it is stated:

Nam hoc natura aequum est neminem cum alterius detrimento fieri locupletiorem. ${ }^{4}$

According to the fragment, it is in line with natural equity never to enrich oneself to the detriment of another. This reference has been generally associated with the so-called condictio indebiti, or the use of the condictio claim in the case of the payment of the indebitum, in a sense that the keeping of a received indebitum is inequitable and that the payment should be transferred back. ${ }^{5}$ The fragment is within the Digesta thus fittingly situated under the $6^{\text {th }}$ titulus of the $12^{\text {th }}$ book, titled De condictione indebiti. Regarding the reception of Roman law and the contemporary legal systems, the principle contained in the fragment has always been associated with the condictio indebiti. ${ }^{6}$ However, it should be noted that this fragment in its context within the Digesta might have been related to a slightly different matter. The immediately preceding fragment, with which there is a connection via the word nam, deals with the ward who has received mutuum without auctoritas tutoris, and who, after having paid his debt upon reaching full age, cannot request back what he has paid. ${ }^{7}$ The following fragment, which has been cited, confirms this by stating that such a conclusion in this case is warranted by natural equity. Therefore, the apparent context for the rule contained in the cited D. 12, 6, 14 (Pomp. 21 ad sab.) is not a confirmation of the main rule for condictio indebiti, but rather a justification for one of its exceptions. ${ }^{8}$

3 More on Pomponius in Kunkel, W., Herkunft und soziale Stellung der römischen Juristen, Weimar, 1952, pp. 170 sq.

4 For it is by nature fair that nobody should enrich himself at the expense of another (translation from Watson, A. (ed.), The Digest of Justinian I-IV (English language translation), Philadelphia, 1985, vol. I, p. 380).

5 Cf. Zimmerman, op. cit. n. 1, p. 852. More on the so-called condictio indebiti in classical law in Kaser, op. cit. n. 1 (1971), p. 596; Zimmerman, op. cit. n. 1, pp. 848 sqq. and in postclassical law Kaser, op. cit. n. 1 (1975), pp. 422 sq.

6 Cf. Ranieri, F., Europäisches Obligationenrecht, Wien, 2009, p. 1089.

7 D. 12, 6, 13, 1 (Paul. 10 ad sab.).

8 Cf. Wollschläger, C., Das stoische Bereicherungsverbot in der römischen Rechtswissenschaft, in: Behrends, O. et al. (eds.), Römisches Recht in der europäischen Tradition. Symposion aus Anlass des 75. Geburstages von Franz Wieacker, Ebelsbach, 1985, pp. 41-88, pp. 79, 81. 
This is true at least in the context of the Digesta, since the two fragments are attributed to different authors, D. 12, 6, 14 (Pomp. 21 ad sab.) to Pomponius, and the immediately preceding D. 12, 6, 13, I (Paul. 10 ad sab.) to Paulus ${ }^{9}$, and therefore the context of the expressed principle in the Pomponius' original work may have been different. However, even in the Digesta the essentially same rule has been given the authority of a general rule of law, therefore applicable also in the field of condictio claims. In the $17^{\text {th }}$ titulus of the $50^{\text {th }}$ book of the Digesta, which deals with different regulae iuris (De diversis regulis iuris antiqui), D. 50, 17, 206 (Pomp. 9 ex var. lect.), by the same Pomponius, reads:

Iure naturae aequum est neminem cum alterius detrimento et iniuria fieri locupletiorem..$^{10}$

The differences in relation to D. 12, 6, 14 (Pomp. 21 ad sab.) cited earlier are that in the present fragment natural law is referenced explicitly, instead of only nature (ius naturae and not natura), and as an additional prerequisite for the prohibition of enrichment, along with the detriment of another, iniuria (unlawfulness) is also named.

Ostensibly, even in the original context of the cited fragments, the condictio claim in the case of indebitum may have been strongly associated with nature and natural law, at least according to Lenel. To begin with, regarding the firstly mentioned D. 12, 6, 14 (Pomp. 21 ad sab.), in the reconstruction of Pomponius' Libri ad Sabinum, Lenel situated the mentioned fragment at the very beginning of the part titled De condictione, apparently awarding it the force of a general rule. ${ }^{11}$ Further, regarding the preceding fragment in Digesta, D. 12, 6, 13, 1 (Paul. 10 ad sab.), what follows in the reconstruction of Paul's Libri ad Sabinum is another general principle, namely Indebiti soluti condictio naturalis est. ${ }^{12,13}$ This is essentially the same principle as the one contained in D. 12, 6, 14 (Pomp. 21 ad sab.). Thus, it could be said that the natural law principle of prohibition of enrichment to the detriment of another, as expressed in D. 12,

9 More on Paulus in Kunkel, op. cit. n. 3, pp. 244 sq.

10 By the law of nature it is fair that no one become richer by the loss and injury of another (translation from Watson, op. cit. n. 4 (vol. IV), p. 483).

11 Lenel, O., Palingenesia iuris civilis II, Leipzig, 1889, p. 129.

12 Lenel, O., Palingenesia iuris civilis I, Leipzig, 1889, p. 1281.

13 The phrase is the beginning of D. 12, 6, 15 pr. (Paul. 10 ad sab.), translated: The condictio is based on natural reason (translation from Watson, op cit. n. 4 (vol. I), p. 380). 
6, 14 (Pomp. 21 ad sab.) and almost identically in D. 50, 17, 206 (Pomp. 9 ex var. lect.), is intrinsically associated with condictio claims. In addition, there are numerous other instances where various applications of condictio claims are explicitly associated with such concepts as natura and ius naturae, with different terminological variants. ${ }^{14,15}$

Besides natural law and its conceptual and terminological derivatives, there are many other similar references in fragments dealing with condictio claims. For example, association of the condictio claims with ius gentium, which was largely influenced by natural law and in which good faith (bona fides) played a very important role. ${ }^{16}$ A good example of this is D. 25, 2, 25 (Marc. 3 reg.), which in the relevant part reads:

(...) nam iure gentium condici puto posse res ab his, qui non ex iusta causa possident. ${ }^{17}$

14 To cite relevant excerpts of some of them: D. 12, 4, 3, 7 (Ulp. $26 \mathrm{ad}$ ed.): (...) sed ipse Celsus naturali aequitate motus putat repeti posse. Quae sententia verior est, (...); D. 12, 6, 64 (Tryph. 7 disp.): (...) ita debiti vel non debiti ratio in condictione naturaliter intellegenda est.

15 More on ius naturale and derived concepts in Roman law in Waldstein, W., Bemerkungen zum ius naturale bei den klassischen juristen, Zeitschrift der Savigny Stiftung für Rechtsgeschichte, Romanistische Abteilung, vol. 105, 1988, pp. 702-711; Levy, E., Natural Law in Roman Thought, Studia et documenta historiae et iuris, vol. 15, 1949, pp. 1-24; Albertario, E., Studi di diritto romano V: Storia, metodologia, esegesi, Milano, 1937, pp. 277 sqq.; Koschembahr-Łyskowski, I., Naturalis ratio en droit classique romain, in: Studi in onore di Pietro Bonfante, vol. III, 1930, pp. 467-498.

16 Cf. mention of ius gentium in the same context in Zimmerman, op. cit. n. 1, p. 853. More on the concept of ius gentium in Roman law generally in Mayer-Maly, T., Das ius gentium bei den späteren Klassikern, IVRA, vol. 34, 1983, pp. 91-102 and Frezza, P., Ius Gentium, Revue internationale des droits de l'antiquite, Mélanges Fernand de Visscher, Bruxelles, 1949, pp. 259-308. On the relationship between ius naturale and ius gentium see Kroger, J. R., The Philosophical Foundations of Roman Law: Aristotle, the Stoics, and Roman Theories of Natural Law, Wisconsin Law Review, 2004, pp. 905-944, pp. 907 sqq. and Zuckert, M., "Bringing Philosophy down from the Heavens": Natural Right in the Roman Law, The Review of Politics, vol. 51, no. 1, 1989, pp. 70-85, pp. 72 sqq.

17 (...) for I hold that in accordance with the jus gentium, property can always be recovered by a condictio from people who possess it without proper title (translation from Watson, op. cit. n. 4 (vol. II), p. 278). Another example would be D. 12, 6, 47 (Cels. 6 dig.), in the relevant part reading: (...) sin autem fideiussor suo nomine solverit quod non debebat, ipsum a stipulatore repetere posse, quoniam indebitam iure gentium pecuniam solvit (...). 
Finally, in a number of fragments condictio claims are associated with concepts such as aequitas and that which is bonum et aequum, along with different terminological derivatives of the expressions. ${ }^{18}$ An example can be found in D. 12, 6, 66 (Pap. 8 quaest.):

Haec condictio ex bono et aequo introducta, quod alterius apud alterum sine causa deprehenditur, reuocare consuevit. ${ }^{19,20}$

This text indicates that a condictio in a specific case was introduced on account of equity (bonum et aequum). This, alongside previously enumerated instances of association of condictio claims with concepts and principles such as natura, ius naturae, ius gentium, aequitas and their derivatives, has been a matter of dispute in literature. To be more specific, it has been argued by some scholars of Roman law that those principles were typical postclassical concepts, interpolated into the classical texts. ${ }^{21}$ One of the main arguments was that condictio in classical

18 More on the concept of aequitas in antiquity generally in Kipp, T., Aequitas, in: Wissowa, G. (ed.), Paulys Real-Encyklopädie der classischen Altertumswissenschaft, vol. I, Stuttgart, 1894, pp. 598 sqq. For the relevance of the concept in Roman law see Pringsheim, F., Aequitas und bona fides, in: Gesammelte Abhandlungen, Heidelberg, 1961, pp. 154-172 (= Conferenze per il XIV Centenario delle Pandette (15 Dicembre 53015 Dicembre 1930), Milano, 1931, pp. 183-214), especially pp. 159 sqq., and more recently and in regard to classical Roman law in Stagl, J. F., Die Ausgleichung von Vorteil und Nachteil als Inhalt klassischer aequitas, in: Mantovani, D.; Schiavone, A. (eds.), Testi e problemi del giusnaturalismo romano, Pavia, 2007, pp. 675-713. For a more specific matter of aequitas evidens see Mayer-Maly, T., Aequitas evidens, in: Becker, W. G.; Carolsfeld, L. S. von (eds.), Sein und Werden im Recht. Festgabe für Ulrich von Lübtow zum 70. Geburtstag am 21. August 1970, Berlin, 1970, pp. 339-352. More on the concept of bonum et aequum in Roman law in Pringsheim, F., Bonum et aequum, in: Gesammelte Abhandlungen, Heidelberg, 1961, pp. 173-223 (= Zeitschrift der Savigny Stiftung für Rechtsgeschichte, Romanistische Abteilung, vol. 52, 1932, pp. 78-155).

19 This condictio, grounded in the idea of what is good and fair, has become the means of reclaiming whatever, belonging to one in the absence of good cause is found in the hands of another (translation from Watson, op. cit. n. 4 (vol. I), p. 388).

20 Further examples include the following: D. 12, 6, 65, 4 (Paul. 17 ad plaut.): Quod ob rem datur, ex bono et aequo habet repetitionem: veluti si dem tibi, ut aliquid facias, nec feceris.; D. 25, 1, 5, 2 (Ulp. 36 ad sab.): (...) Et Marcellus admittit condictioni esse locum: sed etsi plerique negent, tamen propter aequitatem Marcelli sententia admittenda est. Fragment D. 23, 3, 50 pr. (Afr. 8 quaest.) makes a connection with a similar concept of bona fides: (...) Illud ex bona fide est et negotio contracto convenit, ut fundus, quasi sine causa penes maritum esse coeperit, condicatur.

21 See Pringsheim, op. cit. n. 18 (1932), pp. 215 sqq.; Sanfilippo, C., Condictio indebiti I: Il fondamento dell'obbligazione da indebito, Milano, 1943, pp. 56 sqq.; Coing, H., Zum 
law was an actio stricti iuris, and as such could not have had any connections with concepts such as natural law, equity, good faith, etc. ${ }^{22}$ The ostensibly vague and ambiguous nature of those principles was considered uncharacteristic for classical casuistic jurisprudence. The principle of prohibition of enrichment to the detriment of another, which was also brought into connection with condictio claims in the sources, as shown above, was even credited to the influence of Christianity in postclassical law. ${ }^{23}$

However, it seems that it may not be justified to deny a possibility of the influence of such philosophical concepts on an action in classical Roman law in general. In one case at least an action was apparently awarded explicitly on the basis of nature and natural equity, and such an opinion is credited to Labeo, a famous lawyer from the age of August. ${ }^{24}$ In addition, the argument that condictio as an actio stricti iuris could not have had anything to do with concepts such as natural law and equity may not be necessarily correct, taking into account the general functioning of Roman civil procedure. To be more exact, the fact that an action was stricti iuris, and as such generally not subject to any considerations of equity ${ }^{25}$, did not hinder the opportunity of the iudex in the second part of the procedure to interpret the circumstances in a way that would be conducive to the claimant's cause and still within the lines of the strict directions in the

Einfluß der Philosophie des Aristoteles auf die Entwicklung des römischen Rechts, Zeitschrift der Savigny Stiftung für Rechtsgeschichte, Romanistische Abteilung, vol. 69, 1952, pp. 24-59, pp. 40 sqq.; Schwarz, F., Die Grundlage der condictio im klassischen römischen Recht, Münster, 1952, pp. 305 sqq. Cf. Zimmerman, op. cit. n. 1, p. 853.

Pringsheim, op. cit. n. 18 (1932), p. 215; cf. Zimmerman, op. cit. n. 1, p. 853.

See Riccobono, S., Cristianesimo e diritto privato, Rivista di diritto civile, vol. 3, 1911 , pp. 37-70, p. 56; Pringsheim, F., Römische aequitas der christlichen Kaiser, in: Gesammelte Abhandlungen, Heidelberg, 1961, pp. 224-246 (= Acta congressus iuridici internationalis, vol. I, Rim, 1934, pp. 119-152), p. 242.

24 D. 47, 4, 1, 1 (Ulp. 38 ad ed.). The fragment deals with an action against a slave who is directed in the will to be freed and then, after the death of his owner, he steals or destroys something from the inheritance before it has been accepted. In such a case no action would have been prescribed if it was not for such an interpretation of Labeo's, based on considerations of natural law. The fragment is attributed to Ulpian, a famous lawyer from the $3^{\text {rd }}$ century (more on Ulpian in Kunkel, op. cit. n. 3, pp. 245 sqq. and in Honoré, T., Ulpian. Pioneer of Human Rights, Oxford, 2002), but it references Marcus Antistius Labeo, one of the most famous Roman civilian lawyers from the turn of the millennium (more on him in Kunkel, op. cit. n. 3, pp. 114 sq.).

25 More on the characteristics of actiones stricti iuris in Kaser, M.; Hackl, K., Das römische Zivilprozessrecht, München, 1996, p. 334. 
praetor's formula. Zimmerman aptly substantiated this theory on the basis of D. 12, 1, 32 (Cels. 5 dig.), the famous Si et me et Titium fragment. ${ }^{26,27}$

In this fragment one person is asking two different persons to formally promise a loan by stipulatio. One of them directs his debtor to stipulate to give the loan to the potential borrower. After the stipulation, the borrower is in error regarding whose debtor made the stipulation. The question that arises is whether the borrower became the debtor in relation to the person who directed his debtor to make the stipulation or not. This matter is obviously within the realm of interpretation, and the basis for the final decision, in which it is stated that the obligation (and the corresponding action) indeed exists, is the fact that the most important aspect is not a lack of a contractual link between the creditor and the borrower, but the fact that the borrower in the end received the money belonging ultimately to the creditor, which should, for that reason, be subject to reimbursement. ${ }^{28}$ This example fittingly illustrates a possibility

26 D. 12, 1, 32 (Cels. 5 dig.): Si et me et Titium mutuam pecuniam rogaveris et ego meum debitorem tibi promittere iusserim, tu stipulatus sis, cum putares eum titii debitorem esse, an mihi obligaris? subsisto, si quidem nullum negotium mecum contraxisti: sed propius est ut obligari te existimem, non quia pecuniam tibi credidi (hoc enim nisi inter consentientes fieri non potest): sed quia pecunia mea ad te pervenit, eam mihi a te reddi bonum et aequum est (You asked for a loan of money from both myself and Titius, and I told my debtor to make a promise to you. You took a stipulation from him thinking him to be the debtor of Titius. Are you under an obligation to me? My position remains unchanged if, indeed, you have contracted no transaction with me; but it is nearer the mark to suppose that you are under an obligation to me, not because I have lent you money (that can only happen between parties who are agreed), but because my money has come into your hands and it is right and fair that you should give it back (translation from Watson, op. cit. n. 4 (vol. I), p. 362)). See Zimmerman, op. cit. n. 1, pp. 853 sq.

27 For an analysis of the fragment's authenticity see Mayer-Maly, T., Vom Rechtsbegriff der Römer, Österreichische Zeitschrift für öffentliches Recht, vol. 9, no. 2, 1958, pp. 151-173, pp. 161 sq. For an interpretation of this fragment within the context of the Justinianic and Byzantine law see Jong, H. de, A Byzantine interpretation of D. 12,1,32 and similar Digest fragments, Tijdschrift voor Rechtsgeschiedenis, vol. 80, 2012, pp. 47-76.

28 This action for reimbursement was later named condictio Iuventiana in honour of its author, Publius Iuventius Celsus ( $c f$. Hallebeek, J., Some remarks concerning the so-called Condictio Iuventiana (D. 12, 1, 32), Revue internationale des droits de l'antiquite, $3^{\text {e }}$ série, vol. 32, 1985, pp. 247-255, p. 248. More on the action in general in ibid., pp. 247 sqq. More on Celsus in Kunkel, op. cit. n. 3, pp. 146 sq.); admittedly, there is no mention of the condictio in the fragment. This is one of the reasons why, for example, Jan Hallebeek argues that the action in question was the so called actio in id quod pervenit and not a condictio (Hallebeek, J., The condiction as enrichment action in twelfth and thirteenth century legal scholarship, Tijdschrift voor Rechtsgeschiedenis, vol. 63, 1995, pp. 263-272, p. 265, n. 5 and Hallebeek, op. cit. (1985), p. 247 sqq. More on this action in Schulz, F., Die actiones in id quod pervenit und in quantum 
to apply an interpretative tool such as equity without warping the principles of classical Roman law. In the present case, equity (explicitly bonum et aequum) does not entail some intangible principle of general justness, it is a specific and practical application of a commonsensical and sound rule that the obligation should exist between the person to whom the money originally belonged and the person to whom it was ultimately directed.

A similar conclusion could be reached regarding other instances of the association of the analysed principles and concepts with condictio claims. This applies especially in the case of the general principle from D. 50, 17, 206 (Pomp. 9 ex var. lect.), which explicitly mentions iniuria, meaning unlawfulness, as a basis for an enrichment detrimental to another and as such subject to reimbursement. ${ }^{29}$ For this reason, interpolationistic theories regarding the mentioned principles and references to nature, natural law, equity and the like, in association with the general prohibition of enrichment to the detriment of another and in the context of the condictio claims, are more recently generally rejected. ${ }^{30}$

\section{THE CONNECTION OF PRINCIPLES ASSOCIATED WITH CONDICTIO CLAIMS WITH SPECIFIC PHILOSOPHICAL SCHOOLS}

In the previous part we have established that philosophical terminology in the context of condictio claims should not be considered a postclassical interpolation, and that it thus falls within the scope of pre-classical and classical law.

locupletior factus est (inaugural Dissertation), Borna, 1905). However, the fragment obviously deals with mutuum, for which condictio is a standard action (more on mutuum in Kaser, op. cit. n. 1 (1971), pp. 539 sqq.; Kaser, op. cit. n. 1 (1975), pp. 369 sq.; Zimmerman, op. cit. n. 1, pp. 153 sqq.), and is situated under the rubric De rebus creditis si certum petetur et de condictione in the Digesta. Finally, even glossators considered the action in the fragment to be precisely a condictio (cf. Hallebeek, op. cit. (1995), pp. 265 sqq.).

More details on this in Mayer-Maly, T., Privatautonomie und Vertragsethik im Digestenrecht, IVRA, vol. 6, 1955, pp. 128-138, p. 136.

30 See Kaser, op. cit. n. 1 (1975), p. 422; Honoré, T., Gaius, Oxford, 1962, p. 38; Mayer-Maly, op. cit. n. 29, p. 136; Didier, P., Les diverses conceptions du droit naturel a l'oeuvre dans la jurisprudence romaine des II et III siecles, SDHI, vol. 47, 1981, pp. 195-262, p. 224; Wollschläger, op. cit. n. 8, p. 41. More on the relationship between ethics and the law in classical Roman law in Albertario, op. cit. n. 15, pp. 3 sqq., and Albertario, E., Etica e diritto nel mondo classico latino, Rivista internazionale di filosofia del diritto, vol. 12, 1932, pp. 18-35. 
Therefore, the issue of specific philosophical thought or schools that may have influenced condictio claims essentially involves the Greek philosophical schools present in Rome in the pertinent time period. Generally speaking, Greek philosophy did not exert a more substantial influence in Rome before the period of the late Republic, and it began to affect Roman society some time during the course of the $2^{\text {nd }}$ century BC. ${ }^{31}$ Seemingly, the general public was at first indisposed towards Greek philosophy, as it probably appeared to run contrary to the established morals and public order. That may be an explanation of the Senatus consultum de philosophis et rhetoribus from 161 BC, which prohibited Greek philosophers to permanently settle in Rome. ${ }^{32}$ However, already in $156 \mathrm{BC}$ the most famous Athenian philosophical schools, the Academic, the Stoic and the Peripatetic, established their branches in Rome, being represented by Carneades, Diogenes and Critolaus, respectively. This enabled a stronger influence of Greek philosophy in Rome. ${ }^{33}$ Only two of those philosophical schools and their teachings have been brought into connection with the condictio claims and the pertinent principles in literature, namely Peripatetics and Stoics. ${ }^{34}$

\subsection{The Aristotelian and Peripatetic concept of commutative justice}

Prohibition of enrichment to the detriment of another has been brought into connection in literature with the Peripatetic, or essentially Aristotle's ( $4^{\text {th }}$ century BC) concept of justice. ${ }^{35}$ Aristotle deals with justice in the fifth book of

31 Cf. Pohlenz, M., Die Stoa. Geschichte einer geistigen Bewegung, Göttingen, 1948, p. 257; Bund, E., Rahmenerwägungen zu einem Nachweis stoischer Gedanken in der römischen Jurisprudenz, in: Harder, M.; Thielmann, G. (eds.), De iustitia et iure: Festgabe für Ulrich von Lübtow zum 80. Geburtstag, Berlin, 1980, pp. 127-145, p. 128.

32 Bund, op. cit. n. 31, pp. 130 sq.

33 Cf. Behrends, O., Les “veteres” et la nouvelle jurisprudence à la fin de la République, Revue historique de droit français et étranger, vol. 55, 1977, pp. 7-33, p. 24; Bund, op. cit. n. 31, p. 131. Another famous Greek philosophical school is markedly missing from this list, namely the Epicureans. The reason is that this school was considered to be most dangerous for public order in Rome. Their radical materialism was considered outlandish and running contrary to traditional Roman values, while their discouragement of the public engagement and advancement of political careers seemed almost unnatural to the Romans. Hence, it is no surprise that Epicurean philosophers Alkaios and Philiskos (Alcaeus and Philiscus) were banished from Rome during the consulate of Lucius Postumius around 173 BC (cf. Behrends, op. cit., p. 24; Bund, op. cit. n. 31, pp. 129 sqq.). Cf. Wollschläger, op. cit. n. 8, pp. 43 sqq., 46 sqq., with references to further literature.

35 Cf. Schulz, op. cit. n. 28, pp. 19 sqq.; Coing, op. cit. n. 21, pp. 41 sq.; Wollschläger, op. cit. n. 8, p. 43. More on the relevance of the Aristotelian concept of justice in the 
his Nicomachean Ethics. ${ }^{36}$ Therein firstly the general concept of justice is established, which Aristotle considers to represent the perfect virtue. ${ }^{37}$ This abstract concept of universal justice could be associated with law and morality in general. ${ }^{38}$ However, this concept is not subject of his further analysis, where instead he deals in detail with justice in a particular sense. ${ }^{39}$ This so-called particular justice is further divided into two types of justice. One of them is $\tau \dot{\partial} \delta \iota \alpha \nu \varepsilon \mu \eta \tau \iota k o ̀ v$ Síkaıov (tò dianemetikòn díkaion), or distributive justice, meaning a type of justice dealing with the distribution of honours, wealth and other distributable goods in a community, according to which members of a community could be equal

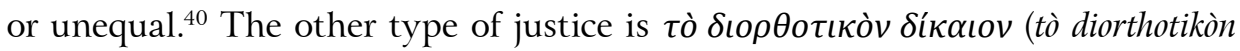
dikaion), or commutative justice, and it is exactly this type of justice that has been associated with condictio claims, and therefore deserves a closer look.

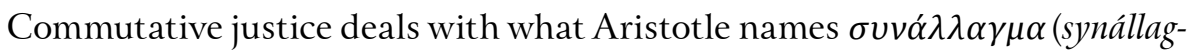
$m a$ ). In the usual translation, the meaning of that word would be a contract or a covenant.$^{41}$ However, as it will be shown, not only contracts were covered by the term in Aristotle's text, so perhaps a better translation would be transactions, although even that should not be understood in a strictly legal sense. ${ }^{42}$ To be more

context of unjustified enrichment in the common law systems in Klimchuk, D., Unjust Enrichment and Corrective Justice, in: Neyers, J. W. et al. (eds.), Understanding Unjust Enrichment, Oxford, 2004, pp. 111-137; Klimchuk, D., The Structure and Content of the Right to Restitution for Unjust Enrichment, University of Toronto Law Journal, vol. 57, no. 3, 2007, pp. 661-684, pp. 674 sqq. and Botterell, A., Property, Corrective Justice, and the Nature of the Cause of Action in Unjust Enrichment, Canadian Journal of Law and Jurisprudence, vol. 20, no. 2, 2007, pp. 275-296. For the same in Croatian law see Vojković, op. cit. n. 2, pp. 23 sq. For a general analysis of the development of the concept of justice in antiquity in the context of Aristotle's philosophy see Manthe, U., Beiträge zur Entwicklung des antiken Gerechtigkeitsbegriffes I: Die Mathematisierung durch Pythagoras und Aristoteles, Zeitschrift der Savigny Stiftung für Rechtsgeschichte, Romanistische Abteilung, vol. 113, 1996, pp. 1-31.

Cf. EN V, 1129a, I sqq.

Cf. EN V, 1129b, 25 sqq.

Lee, H. D. P., The Legal Background of Two Passages in the Nicomachean Ethics, The Classical Quarterly, vol. 31, no. 3-4, 1937, pp. 129-140, p. 129.

Ibid.

EN V, 1130b, 30 sqq.

See translation of $\sigma v v \alpha \dot{\alpha} \lambda \lambda \alpha \gamma \mu \alpha, \alpha \tau o \varsigma, \tau o ́$ in Liddell, H. G. et al., A Greek-English Lexicon, Oxford, 1940, available at: http://www.perseus.tufts.edu (last accessed in April 2019).

42 Cf. translations in Reeve, C. D. C. (ed.), Aristotle, Nicomachean Ethics, Cambridge, 2014, p. 81; Bartlett, R. C.; Collins, S. D. (eds.), Aristotle's Nicomachean Ethics, Chica- 


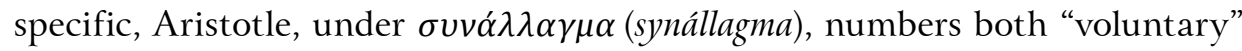

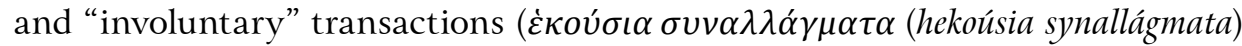

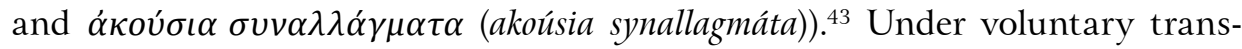
actions Aristotle lists selling, buying, lending with interest, pledging, giving free use of something, depositing, and hiring out. Involuntary transactions are futhrer divided into those that arise in a clandestine way ( $\lambda \alpha \theta \rho \alpha \tilde{\imath} \alpha$ (lathraĩa), for example theft, adultery, poisoning, pandering, enticing slaves away, murder by treachery, betrayal) and those that involve force (Bía $\alpha$ (biaia), for example assault, imprisonment, murder, abduction, disabling, verbal abuse, insulting treatment).

Besides, Aristotle maintains that commutative justice is achieved by establishing a just division of goods between relevant subjects, and gives a detailed account and a formula for how it may be achieved. ${ }^{44}$ Further, Aristotle gives an example for the application of commutative or corrective justice. ${ }^{45}$ He provides an illustration where one person injures or kills another, and then the judge has to establish a balance between them, since the act of injury on the one side and the corresponding suffering on the other constitute unequal parts in a division. Although Aristotle concedes that the following terms may not be applicable in all cases (the case of physical injury manifestly being one), he still defines such transactions as having a "profit" on one side and a "loss" on the other, and states that the role of the judge is to level them out.

When evaluating this Aristotle's treatise on justice, it should be noted that it is generally of a non-legal character. ${ }^{46}$ More to the point, it serves as an introduction and context for his philosophical definition of commutative justice, and does not form part of a legal classification. Roughly, perhaps his division on voluntary and involuntary transactions could be associated with Roman obligationes ex contractu and ex delicto. ${ }^{47}$ However, the question remains where in such a system condictio claims could be classified. They definitely do not fall

go, 2011, p. 95; Ross, D.; Brown, L. (eds.), Aristotle, The Nicomachean Ethics, Oxford, 2009, p. 84. For the role of the Aristotle's concept of commutative justice in contract law see Harke, J. D., Vorenthaltung und Verpflichtung. Philosophische Ansichten der Austauschgerechtigkeit und ihr rechtshistorischer Hintergrund, Berlin, 2005, pp. 11 sqq., with further references.

EN V, 1131a, I sqq.

44 EN V, 113lb, 1 sqq.

45 EN V, 1132a, 5 sqq.

Cf. Harrison, A. R. W., Aristotle's Nicomachean Ethics, Book V, and the Law of Athens,

The Journal of Hellenic Studies, vol. 77, no. 1, 1957, pp. 42-47, pp. 46 sq.

47 Cf. Lee, op. cit. n. 38, p. 130. 
under voluntary obligations, since they do not arise voluntarily. On the other hand, involuntary obligations in Aristotle's system comprise what is defined as delicta in Roman law, and that is a separate field altogether. ${ }^{48}$ So essentially, in this Aristotle's classification and explication of justice there is no place for a concept such as condictio claims in Roman law.

Further, establishing a balance between two subjects according to the previously mentioned Aristotle's formula is definitely a worthy contribution to the concepts of justice and equity. However, it is not specifically applicable in the field of condictio claims. Generally speaking, the way in which the balance should be achieved in coordinated pecuniary relationships is fairly self-explanatory. The party that has been enriched to the detriment of another should be indebted to that person in the amount in which the detriment occurred, and no special formula, as the one Aristotle lays out, is actually needed for such a conclusion. In addition, Aristotle's example for commutative justice is completely inappropriate in the context of condictio claims. He describes a procedure ( $\delta i ́ \kappa \eta$ $(d i k e))$ in which a judge delivers a sentence against a person who injured or killed another person. While it could be argued that one person did suffer a detriment here, perhaps even pecuniarily calculable to the amount of pertinent medical (or funerary) expenses, the person inflicting the injury definitely did not gain anything legally relevant from such a "transaction" in itself. ${ }^{49}$ The imbalance that Aristotle explains is an imbalance in the justice as a theoretical and abstract equilibrium existing between members of a society in status quo, which obviously cannot always be defined in pecuniary terms. For that reason, its application in any private legal context is dubious at best.

Finally, even on a general level, Aristotle's philosophy is not likely to have influenced Roman law in any relevant measure. For example, in other places in his work Aristotle explicitly condemns commercial activity oriented towards profit and loaning with interest. ${ }^{50}$ This is something that obviously could not have been accepted as general ethics of Roman law, which dealt extensively with

48 As can be seen in the general literature on condictio claims cited in $\mathrm{n}$. 1 , in the Justinianic sources they are classified as obligations arising quasi ex contractu, which means that they are similar to but still sufficiently different from contracts (due to a lack of intention of the parties to create an obligation). More on delictual obligations in Roman law in Kaser, op. cit. n. 1 (1971), pp. 609 sqq.; Kaser, op. cit. n. 1 (1975), pp. 425 sqq.; Zimmerman, op. cit. n. 1, pp. 902 sqq.

49 As has been noted previously, even Aristotle was aware of the questionable applicability of the terms "profit" and "loss" in the example. Cf. Wollschläger, op. cit. n. 8, pp. 44 sq. 
such matters and did not consider them to be unethical in themselves. This may be one of the reasons why Aristotle's and general Peripatetic concept of aspiring to medial ground as a perfect way to achieve justice and all the other virtues was marginalised in Rome, and was considered to be weak and without any practical significance. ${ }^{51}$ It is not surprising, therefore, that not one Roman lawyer is considered to be a follower of the Peripatetic school. ${ }^{52}$

For all the abovementioned reasons, it is most likely that Aristotle's concept of commutative justice did not exert any significant influence on the Roman legal principles associated with condictio claims, especially prohibition of enrichment to the detriment of another. Aristotle's explication of justice in general, and of commutative justice in particular, is not particularly suitable for condictio claims and the accompanying principles in the sources. Consequently, any association of Aristotle's commutative justice in the context of condictio claims is probably a post facto connection between the two phenomena. Aristotle's concept is without a doubt a very valuable contribution to the philosophical concept of justice, but has no larger bearing in a strictly legal context, and it most likely did not have a role in the creation and application of the condictio claims in the pre-classical and classical Roman law.

\subsection{Stoic prohibition of enrichment to the detriment of another}

Another philosophical school that may have influenced philosophical principles associated with condictio claims is Stoicism. On a general level, Stoics are among the rare philosophical schools that left a significant trace in Rome. ${ }^{53}$ Stoic ethics, the segment of Stoic philosophy most accepted in Rome ${ }^{54}$, dealt with the problem of permissible and impermissible human actions, thus being closely associated with Roman jurisprudence. ${ }^{55}$ In the context of pre-classical and classical Roman law, in which condictio claims may have been influenced, primarily relevant are the so-called middle Stoics. The most prominent representatives thereof were Panaetius of Rhodos (c. 180-110 BC) and his pupil Posidonius of Apameia (135-51 BC). ${ }^{56}$ The great number of prominent Romans counting as

51 Behrends, op. cit. n. 33, p. 24.

52 Bund, op. cit. n. 31, p. 134.

53 Cf. Pohlenz, op. cit. n. 31, p. 276; Behrends, op. cit. n. 33, p. 24; Bund, op. cit. n. 31, p. 128.

54 Bund, op. cit. n. 31, p. 142.

55 Cf. Pohlenz, op. cit. n. 31, pp. 259 sqq.; Behrends, op. cit. n. 33, p. 34; Bund, op. cit. n.

31, pp. 133 sqq.

56 Wollschläger, op. cit. n. 8, p. 48. 
followers of this school at the time testifies to its significance. ${ }^{57}$ Among them were many Republican lawyers, such as Quintus Mucius Scaevola (augur), Quintus Aelius Tubero and Publius Rutilius Rufus (pupils of Panaetius of Rhodos), Lucius Furius Philus, Manius Manilius, Quintus Mucius Scaevola (pontifex) and Sextus Pompeius, while Pacuvius Antistius Labeo (father of famous Marcus Antistius Labeo) and Servius Sulpicius Rufus are presumed as followers. ${ }^{58}$

Marcus Tullius Cicero (106-43 BC), who may be said to have embodied an eclectic influence of Greek culture on Rome, was also under a strong influence of Stoic teachings. During the period of the middle Stoics he left a strong mark on Roman jurisprudence. ${ }^{59}$ In the matters of justice and equity he is considered to have been under a direct influence of the main representatives of Stoic thought of the time, the already mentioned Panaetius and Posidonius. ${ }^{60}$ For this reason, Cicero's work deserves a closer look in this analysis. In that context, prohibition of enrichment to the detriment of another may be brought into connection with a general prohibition of damage or of incurring an injury to another, which existed even in the early Stoic philosophy. ${ }^{61}$ This principle is also enunciated by Cicero in his work De finibus bonorum et malorum, in CIC. fin. III, xxi, 71:

Ius autem, quod ita dici appellarique possit, id esse natura, alienumque esse a sapiente non modo iniuriam cui facere, verum etiam nocere. ${ }^{62}$

Prohibition of incurring damage to another person can be found in the works of later Stoic writers, such as Seneca (c. 1-65), for example in his Ad Lucilium

57 For example, Marcus Vigellius, Caius Laelius, Caius Fannius, Spurius Mummius, Cato Uticensis, Scipio Nasica, and to an extent Marcus Terentius Varro (Bund, op. cit. n. 31, pp. 131 and 137, n. 85).

58 Bund, op. cit. n. 31, pp. 143 sq.

59 Cf. Pohlenz, op. cit. n. 31, p. 269; Levy, op. cit. n. 15, pp. 2 sqq.; Bund, op. cit. n. 31, p. 128. More on natural law as a result of the influence of Stoic teachings in Cicero's work in Alonso, F. L., Cosmopolitanism and Natural Law in Cicero, in: Contreras, F. J. (ed.), The Threads of Natural Law. Unravelling a Philosophical Tradition, Dordrecht, 2013, pp. 27-36. More on Cicero's influence on the law and lawyers in Harries, J., Cicero and the Jurists, London, 2006 and Powell, J.; Paterson, J. (eds.), Cicero the Advocate, Oxford, 2004.

Pohlenz, op. cit. n. 31, p. 269; Wollschläger, op. cit. n. 8, p. 48.

${ }^{61} C f$. Wollschläger, op. cit. n. 8, p. 50.

62 Right moreover, properly so styled and entitled, exists (they aver) by nature; and it is foreign to the nature of the Wise Man not only to wrong but even to hurt anyone (translation from Rackham, H. (ed.), Cicero, De finibus bonorum et malorum, Cambridge, 1931, p. 291). 
epistulae morales. ${ }^{63}$ In both examples prohibition of incurring damage to another person is associated with nature or natural law. This principle was reflected in classical Roman law, for example in Ulpian's famous praecepta iuris. ${ }^{64}$

However, explicit prohibition of enrichment to the detriment of another, which could be considered a more specified instance of the prohibition of causing damage or injury, exists only in the philosophy of the middle Stoics. This is most adequately expressed by Cicero in his De officiis, in CIC. off. III, v, 21:

Detrahere igitur alteri aliquid et hominem hominis incommode suum commodum augere magis est contra naturam quam mors, quam paupertas, quam dolor, quam cetera quae possunt aut corpora accidere aut rebus externis. ${ }^{65}$

Cicero here declares how acquisition of property to the detriment of another is contrary to nature, and compares this phenomenon to calamities such as death, poverty, pain and any other infliction upon person or property.

Although this rule is not stated in writings defining basic Stoic principles, Cicero announces it with the words sed redeo ad formulam, thus defining it as a formula of Stoic ethics. ${ }^{66}$ The relevance of this ethical maxim stems from a controversy between Academic and Stoic philosophy in the second century BC. These two schools, both represented in Rome, had a fundamental disagreement regarding the question whether one should behave honestly and honourably, or whether the best course of action is to pursue only that which is beneficial and advantageous for an individual (the conflict between honestum and utile) ${ }^{67}$ Philosopher Carneades (c. 213-128 BC), representing the Academics, argued that the true wisdom lies in doing only what is advantageous, or utile, for an individual. He maintained that it was impossible to strive only for what is honestum,

63 SEN. ep. 95, 52.

64 D. 1, 1, 10, 1 (Ulp. 1 reg.). More on this fragment and its philosophical implications in Petrak, M., Plato and Ulpian's praecepta iuris, Fundamina, vol. 20, no. 2, 2014, pp. 694-701 and Diesselhorst, M., Die Gerechtigkeitsdefinition Ulpians in D. 1, 1, 10 pr. und die Praecepta iuris nach D. 1, 1, 10, I sowie ihre Rezeption bei Leibniz und Kant, in: Behrends, O. et al. (eds.), Römisches Recht in der europäischen Tradition. Symposion aus Anlass des 75. Geburstages von Franz Wieacker, Ebelsbach, 1985, pp. 185-212.

65 Well then, for a man to take something from his neighbour and to profit by his neighbour's loss is more contrary to nature than is death or poverty or pain or anything else that can affect either our person or our property (translation from Miller, W. (ed.), Cicero, De officiis, London, 1913, p. 289).

66 CIC. off. III, iv, 20 (cf. Wollschläger, op. cit. n. 8, p. 47.).

67 Behrends, op. cit. n. 33, p. 24; Bund, op. cit. n. 31, pp. 131 sqq.; Wollschläger, op. cit. n. 8 , p. 47 . 
since that would entail negating an innate instinct towards self preservation. ${ }^{68}$ Therefore, the only ethical principle should be to do what is utile, or useful and advantegeous for an individual.

This was unacceptable for Stoic philosophy and ethics. Cicero explicitly states that his teacher Posidonius considers the ethical conundrum of doing what is honestum or utile to be a matter of paramount importance in philosophy. ${ }^{69}$ In Stoic ethics this problem is solved by arguing that while something is advantageous for one person and simultaneously disadvantageous or detrimental to another, it is not truly utile. ${ }^{70}$ Such an ethical maxim does not prohibit behaviour the purpose of which is to achieve a more advantageous or beneficial position of an individual, it only prohibits such behaviour which concurrently damages another person. This ethical position was very welcome in Rome (as it is likely to be in any orderly functioning society). On the one hand, it does not burden advancement of a personal career or profit with the impression of apparent moral dubiousness. On the other hand, it establishes reasonable limits to advancement of personal gain, which enable every member of a given society to try to further one's interests while not infringing anybody and everybody else's.

The previously cited and analysed fragments of Pomponius, relevant in the context of the prohibition of enrichment to the detriment of another in Roman law in general, and with condictio claims and unjustified enrichment specifically, express an extremely similar ethical maxim. According to one of them, prohibition of enrichment detrimental to another person runs contrary to nature, and the other explicitly cites natural law as the basis for the same opinion. ${ }^{71}$ Actually, the only relevant difference in relation to Cicero's expression of the Stoic formula is that Cicero, when explaining gain and loss, uses the phrases

68 Wollschläger, op. cit. n. 8, p. 47; Bund, op. cit. n. 31, pp. 132 sq.

69 CIC. off. III, ii, 8: Quem locum miror a Posidonio breviter esse tactum in quibusdam commentariis, praesertim cum scribat nullum esse locum in tota philosophia tam necessarium (And I am surpised that Posidonius has but briefly touched upon this subject in certain memoirs of his, and especially, as he states that there is no other topic in the whole range of philosophy so essentially important as this (translation from Miller, op. cit. n. 65, p. 277)).

70 CIC. off. III, xxx, 110: Est enim nihil utile, quod idem non honestum, nec quia utile honestum, sed quia honestum utile (For nothing can be expedient which is not at the same time morally right; neither can a thing be morally right just because it is expedient, but it is expedient because it is morally right (translation from Miller, op. cit. n. 65, p. 391)). This is expressed more concisely in CIC. off. III, xii, 49: Maneat ergo, quod turpe sit, id nunquam esse utile (Let it be set down as an established principle, then, that what is morally wrong can never be expedient (translation from Miller, op. cit. n. 65, p. 319)).

71 See D. 12, 6, 14 (Pomp. 21 ad sab.) and D. 50, 17, 206 (Pomp. 9 ex var. lect.) analysed above. 
commodum and incommodum, while Pomponius uses locupletior and detrimentum. Analogous and completely relatable pairs of terms exist in numerous other places throughout Digesta. ${ }^{72}$

This should not be surprising. Pomponius was a member of the Sabinian school, which is considered to have been under a stronger influence of Stoic teachings. ${ }^{73}$ Besides that, not only the mentioned Pomponius fragments can be brought into connection with the Stoic school. As can be seen above, the other fragments dealing with condictio claims in classical Roman law overflow with references to concepts such as natura, ius naturae, ius gentium, aequitas, bonum et aequum and other derived terms. Those concepts can be most clearly associated with the Stoic philosophy. ${ }^{74}$ Therefore, it could be concluded that the concept of prohibition of enrichment to the detriment of another, along with the general association of natural law, nature, equity and justice, etc. in the context of

72 For example, locupletior and pauperior: D. 24, 1, 5, 8 (Ulp. 32 ad sab.), D. 24, 1, 25 (Clem. 5 ad 1. iul. et pap.) and D. 24, 3, 66, 7 (Iav. 6 ex post. lab.), also lucrum and damnum: D. 2, 10, 3, 1 (Iul. 2 Dig.), D. 2, 15, 8, 22 (Ulp. 5 de omn. trib.), D. 4, 3, 1 pr. (Ulp. 11 ad ed.), D. 4, 3, 28 (Gai. 4 ad ed. provinc.), D. 4, 6, 18 (Paul. 12 ad ed.), D. 11, 7, 14, 1 (Ulp. 25 ad ed.), D. 23, 3, 6, 2 (Pomp. 14 ad sab.), D. 23, 3, 16 (Ulp. 34 ad sab.) and D. 27, 9, 13, 1 (Paul. 1.S. ad or. severi.). Expression damnum is replaced by iactura in D. 5, 3, 38 (Paul. 20 ad ed.), D 14, 3, 17, 4 (Paul. 30 ad ed.) and D. 20, 5, 12, 1 (Tryph. 8 disp.) (cf. Wollschläger, op. cit. n. 8, pp. 55 sqq.). Terminological pair commodum and incommodum, used by Cicero in the mentioned formula, is otherwise used in Digesta in the definition of property (bona), which is defined as comprising both commoda and incommoda (benefits and disadvantages) in D. 50, 16, 83 (Iav. 5 ex plaut.). Also, the pair appears in D. 50, 17, 10 (Paul. 3 ad sab.), where it is stated that it is in accordance with nature that the person enjoying commoda should also bear the burden of the pertinent incommoda: Secundum naturam est commoda cuiusque rei eum sequi, quem sequentur incommoda).

73 Honoré, op. cit. n. 30, pp. 25 sqq.

74 Cf., for example, Colish, M. L., The Stoic Tradition from Antiquity to the Early Middle Ages I.: Stoicism in Classical Latin Literature, Leiden, 1990, pp. 31 sqq. Vander Waerdt, in his excellent and very detailed analysis regarding the influence of the Stoic philosophical concept of natural law on classical Roman jurisprudence, is generally suspicious regarding the Stoic provenance of the said concepts (Vander Waerdt, P. A., Philosophical Influence on Roman Jurisprudence? The Case of Stoicism and Natural Law, in: Haase, W. (ed.), Aufstieg und Niedergang der römischen Welt, vol. 36, 7 (Philosophie, Wissenschaften, Technik. Philosophie), Berlin, 1994, pp. 4851-4900, pp. 4866, $4879,4893)$. His conclusion is that while Stoic etymology may well have indeed been used, it did not bring any substantial change to the legal reasoning of Roman law (op. cit., pp. 4894 sq.), which is actually very similar to the conclusion reached in this text in regard to the philosophical background of condictio claims. 
condictio claims, in principle stem from the Stoic philosophy and ethics. ${ }^{75}$ The question that remains is: what was the actual reach of this influence, or what role did the mentioned principles and concepts have in the creation and application of condictio claims in classical Roman law? These questions are addressed below.

\section{THE RELEVANCE OF PHILOSOPHICAL PRINCIPLES FOR THE CLASSICAL CONDICTIO CLAIMS}

Generally speaking, opinions on the scope of influence of Stoic philosophy on Roman law differ. In the older theory the view was held that concepts such as natural law, nature, equity, etc. stem from the Stoic philosophical school, and there were no doubts that they exerted a direct influence in many different areas of pre-classical and classical Roman law. ${ }^{76}$ On the other hand, a repudiation of any substantial philosophical influence also exists in literature. Extant philosophical concepts in the sources are thus consequently attributed to a postclassical vulgarisation, abstract philosophical and moral concepts, Christianity and the like. ${ }^{77}$ A sort of a median viewpoint holds that philosophical concepts and principles generally did not really have any substantial influence on Roman law. However, it is stated that they did have a very important role in the field of legal systematisation and categorisation, as well as regarding philosophemes and terminology taken over in Roman law from certain philosophical schools. ${ }^{78}$

75 This is very convincingly supported by Christian Wollschläger in Wollschläger, $o p$. cit. n. 8, pp. 46 sqq. For a critique of this opinion see Kupisch, B., Ungerechtfertigte Bereicherung. Geschichtliche Entwicklungen, Heidelberg, 1987, p. 26, n. 38.

76 This opinion is primarily creditable to Moritz Voigt and his work Das jus naturale, aequum et bonum, und jus gentium der Römer (see Voigt, M., Das jus naturale, aequum et bonum und jus gentium der Römer II: das jus civile und jus gentium bei Römer, Leipzig, 1858). See also Voigt, M., Römische Rechtsgeschichte II, Leipzig, 1899, especially pp. 97 sqq. (cf. Colish, op. cit. n. 74, p. 343).

77 Most insistently and famously by Emilio Albertario, $c f$. for example Albertario, op. cit. n. 15, pp. 277 sqq.; Albertario, op. cit. n. 30, pp. 3 sqq.; Colish, op. cit. n. 74, p. 355. Cf. Vander Waerdt, op. cit. n. 74, p. 4866.

78 Pringsheim, F., Jus aequum und jus strictum, in: Gesammelte Abhandlungen, Heidelberg, 1961, pp. 131-153 (= Zeitschrift der Savigny Stiftung für Rechtsgeschichte, Romanistische Abteilung, vol. 42, 1921, pp. 643-668); Pringsheim, op. cit. n. 18 (1932), pp. 173 sqq.; Zulueta, F. de, The Development of Law under the Republic, in: Cook, S. A. et al. (eds.), Cambridge Ancient History, vol. 9, Cambridge, 1932, pp. 842-881, pp. 868 sqq.; Buckland, W. W., Classical Roman Law, in: Cook, S. A. et al. (eds.), Cambridge Ancient History, vol. 11, Cambridge, 1936, pp. 806-844, pp. 817 sq.; Schulz, F., History of 
This theory is most likely closest to the truth. However, the specific subject of condictio claims deserves a closer look.

One of the first things to point out in that context is the fact that the prohibition of enrichment to the detriment of another, associated with condictio claims, is not only associated with nature generally, but also explicitly with natural law, or ius naturale. ${ }^{79}$ In that way a more specific and concrete legal outlook is assumed, and matters are not dealt with on an intangible philosophical level. This is not a coincidence. In the Roman legal system matters such as equity, justice, etc. have a very important role, but they can be taken into account only inasmuch as they may be realised within the confines of the ius civile. ${ }^{80}$ This by no means implies a necessarily rigid legal formalism. This assertion may be explained by the famous definition of ius as ars boni et aequi, where the law is considered to be the art of what is good and righteous ${ }^{81}$ In such a system, equity and justice are actually realised through ius, and for that reason ius holds a sort of a primary and principal position through which justice is achieved, and not the other way around, according to which justice may be considered a general philosophical concept with which ius may or may not be in tune, or only to an extent. In that sense, jurisprudence has a sort of a sacred duty of actualising justice and bringing it to life through interpretation and application of the law. So, in the context of condictio claims as well as in other areas of Roman law, philosophical concepts and principles above all have a strong and explicit legal outlook, and should not be dismissed on account of their apparent intangible philosophical nature.

Further, if we consider influence of the Stoic philosophemes and terminology to exist only on a superficial level, this does not mean that essentially similar principles did not exist underneath, in the internal system of Roman law and its inherent disposition towards actualisation of equity and justice within the confines of ius civile. In other words, elements from the Stoic philosophy and

Roman Legal Science, Oxford, 1946, pp. 62 sqq., 84 sqq., 98; Coing, op. cit. n. 21, pp. 24 sqq.; Colish, op. cit. n. 74, p. 346; Vander Waerdt, op. cit. n. 74, pp. 4856 sqq.

79 See D. 50, 17, 206 (Pomp. 9 ex var. lect.) analysed above.

80 Colish, op. cit. n. 74, p. 364.

81 D. 1, 1, 1 pr. (Ulp. 1 inst.). More on this definition and generally on the concpet of law and justice in the writings of Roman lawyers in Gallo, F., "Ars boni et aequi" e "ius naturale", SDHI, vol. 75, 2009, pp. 15-42; Sokolowski, P. von, Der Gerechtigkeitsbegriff des römischen Rechtes, in: Studi in onore di Pietro Bonfante, vol. 1, Milano, 1930., pp. 183-200; Waldstein, W., Aequitas und summum ius, in: Slapnicar, K. (ed.), Tradition und Fortentwicklung im Recht. Festschrift zum 90. Geburtstag von Ulrich von Lübtow am 21. August 1990, Rheinfelden, 1991, pp. 23-33. 
ethics may have been used to justify and reinvigorate concepts both essentially and strictly legal (and not merely or mainly philosophical) and distinctively Roman. As a matter of fact, Cicero is known to have used Stoicism to justify religious or moral attitudes which had a different, autonomous origins. ${ }^{82}$ For example, Cicero invokes the bellum iustum procedure from the history of Rome as a good example of an ethical and orderly initiation of war. ${ }^{83}$ With that, he associates just war as an ethical concept, adequate for the Stoic philosophy and ethics, with an ancient Roman concept from ius fetiale in which such an ethical concept is considered to have been embodied ${ }^{84}$

In the mentioned example, orderly and just initiation of war as an ethically desirable matter in the Stoic philosophy is supported by an ancient Roman practice, most likely in order to give the concept a guise of authority and Roman authenticity. A similar thing may have happened, although the other way around, in the field of condictio claims. Stoic ethical concepts such as equity, natural law, justice, etc., as well as the Stoic prohibition of enrichment to the detriment of another, being very popular in the period of pre-classical and classical Roman law, may have been used to justify an otherwise completely Roman concept from earlier times. Most important instances of the use of condictio claims in classical Roman law were either already covered by the ancient legis actio per condictionem, or were closely associated with it and originated from the same legal reasoning. ${ }^{85}$ Although legis actio per condictionem was the youngest of the legis actiones, stemming most likely from some time between the end of the third and first half of the second century $\mathrm{BC}^{86}$, it still predated the most fruitful period of influence of middle Stoicism on Roman jurisprudence, which happened in the subsequent periods, as laid out above. Therefore, the aim of Cicero's formula may have been to re-affirm an ethical principle that was in the legal field actually already essentially embodied in the application of the legis actio per condictionem. Association of condictio claims with concepts such as

82 Colish, op. cit. n. 74, p. 127.

83 CIC. rep. II, xvii, 31 and III, xxiii, 35, as well as CIC. off. I, xi, 36. More on this procedure in Kaser and Hackl, op cit. n. 25, pp. 111 sqq. and Held, H.-R., Podrijetlo postupka legis actio per condictionem, Zbornik Pravnog fakulteta u Zagrebu, vol. 67, no. 2, 2017, pp. 197-227, pp. 201 sqq., with references to sources and further literature.

Cf. Hausmaninger, H., "Bellum iustum” und “iusta causa belli” im älteren römischen Recht, Österreichische Zeitschrift für öffentliches Recht, vol. 9, no. 3-4, 1961, pp. 335345, pp. 342 sqq.

85 See literature in n. 1. Cf. Held, op. cit. n. 83.

86 Kaser, Hackl, op. cit. n. 25, p. 111, n. 5 and 6. 
justice and equity, in fact, should not be surprising in the least, since the legis actio per condictionem procedure in its original application was closely associated with the concepts of iustum and fides. ${ }^{87}$

In that way an imprint of Stoic philosophy on Roman law may have been the use of Stoic terminology and general guise of Stoic ethics by Roman lawyers to justify legal reasoning already extant in Roman legal sources regardless of the Greek philosophy. Consequently, although superficially Stoic, invocation of principles such as natural law, equity and the like was not an un-Roman philosophising or an imposition of an extra-legal and supra-legal principle. ${ }^{88}$ It was an affirmation of the application of a perfectly sound legal logic, based on an already existing matter of Roman law. In the part of this text dealing with the problem of the origins of the principles and concepts associated with condictio claims, in the context of the famous Si et me et Titium fragment (D. 12, 1, 32 (Cels. 5 dig.)), it was mentioned how in at least one instance a condictio claim was granted by interpretation and taking into account that which is right and fair (bonum et aequum). Consequently, even if the respective principles did help an interpretative widening of the scope of condictio claims and their application to situations unenvisaged previously in the legis actio per condictionem strictly speaking, they still followed the same logic and never fell outside its conceptual scope. ${ }^{89}$ With such a conclusion, the use of Stoic elements in the context of condictio claims may neither be considered their conceptual root, nor a postclassical philosophical addition. However, it should also not be considered only an embellishment, a fad of the time used for the sake of itself. It may well have been, we hope to have at least convincingly suggested, a reinvigoration and a reaffirmation of a perfectly sound and typically Roman legal matter with the spirit of the times.

\section{CONCLUSION}

The problem of the philosophical background of the condictio claims in classical Roman law, while being an intricate matter, is of such a nature that a possible

${ }_{87}$ More on this in Held, op. cit. n. 83, pp. 197 sqq. Cf. Kaser, op. cit. n 1 (1971), p. 111 $s q q$. and the referenced literature, especially in n. 2.

88 Cf. Maschi, C. A., Il diritto naturale come ordinamento giuridico inferiore?, in: L'Europa e il diritto romano. Studi in onore di Paolo Koschaker, vol. II, Milano, 1954, pp. 425-437, pp. 436 sq.; Colish, op. cit. n. 74, pp. 365 sqq. Similar conclusion is reached by Vander Waerdt regarding the ostensibly Stoic philosophical concept of natural law in the classical Roman jurisprudence (Vander Waerdt, op. cit. n. 74, pp. 4887, 4894 sq.).

$89 \mathrm{Cf}$. the emphasis on abstractness of both legis actio per condictionem and condictio claims in Zimmerman, op. cit. n. 1, p. 835. 
explanation of one issue associated with it inevitably has consequences for all the other different aspects. In that sense, the viewpoint that the philosophical references in the context of condictio claims most likely have pre-classical and classical roots narrows down possible philosophical influences, and helps to determine their actual scope. In order to achieve more clarity and an orderly exposition of the argument, this text has dealt with the three mentioned matters separately.

There are no serious reasons to doubt the pre-classical and classical origins of principles and concepts such as natura, ius naturale, aequitas, etc., explicitly associated in the sources with the prohibition of enrichment to the detriment of another and with condictio claims. With that, the matter of their inspiration is narrowed down to certain Greek philosophical schools. Although often associated with condictio claims, Aristotle's and the Peripatetic concept of commutative justice actually has little or no importance for them. A more direct line of influence, most notably in Cicero's work, can be found in relation to the Stoic prohibition of enrichment to the detriment of another, along with all the other principles and concepts of Stoic philosophy and ethics in the relevant context. Finally, the mentioned principles and concepts may be considered to have had a specific role in the matter. They definitely did not give cause to the creation of condictio claims, which were rooted in the ancient Roman legis actio per condictionem, although they did on occasion help widen the application of condictio claims via interpretation, all the while maintaining their essential function. The analysed principles and concepts were also most likely not only mere verbiage or a suitable decoration. We hope that we have demonstrated that they at least possibly were a tool for reaffirming a typical and ancient Roman legal principle already embodied in the application of legis actio per condictionem.

\section{SOURCES}

CIC. fin. = Marcus Tullius Cicero, De finibus bonorum et malorum (Schiche, T. (ed.), M. Tulli Ciceronis scripta quae manserunt omnia, fasc. 43.: de Finibus Bonorum et Malorum, Leipzig, 1915).

CIC. off. = Marcus Tullius Cicero, De officiis (Miller, W. (ed.), Cicero: De Officiis, London, 1913).

CIC. rep. = Marcus Tullius Cicero, De Republica (Müller, C. F. W. (ed.), Librorum de Re Publica Sex, Leipzig, 1889).

D. = Digesta seu Pandectae Iustiniani (Mommsen, T. et al. (eds.), The Digest of Justinian, vol. 1-4, Philadelphia, 1985). 


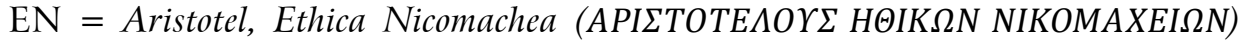

(Greek text from Bywater, I. (ed.), Aristotelis Ethica Nicomachea, Oxford, 1962; English translation from Reeve, C. D. C. (ed.), Aristotle, Nicomachean Ethics, Cambridge, 2014).

SEN. ep. = Lucius Annaeus Seneca, Ad Lucilium epistulae morales (Gummere, R. M. (ed.), Ad Lucilium epistulae morales, vol. 3, Cambridge, 1925).

\section{LITERATURE}

Albertario, E., Etica e diritto nel mondo classico latino, Rivista internazionale di filosofia del diritto, vol. 12, 1932, pp. 18-35.

Albertario, E., Studi di diritto romano V: Storia, metodologia, esegesi, Milano, 1937.

Alonso, F. L., Cosmopolitanism and Natural Law in Cicero, in: Contreras, F. J. (ed.), The Threads of Natural Law. Unravelling a Philosophical Tradition, Dordrecht, 2013, pp. 27-36, https://doi.org/10.1007/978-94-007-5656-4_2.

Bartlett, R. C.; Collins, S. D. (eds.), Aristotle's Nicomachean Ethics, Chicago, 2011, https://doi.org/10.7208/chicago/9780226026763.001.0001.

Behrends, O., Les “veteres” et la nouvelle jurisprudence à la fin de la République, Revue historique de droit français et étranger, vol. 55, 1977, pp. 7-33.

Botterell, A., Property, Corrective Justice, and the Nature of the Cause of Action in Unjust Enrichment, Canadian Journal of Law and Jurisprudence, vol. 20, no. 2, 2007, pp. 275-296, https://doi.org/10.1017/s0841820900004215.

Buckland, W. W., Classical Roman Law, in: Cook, S. A. et al. (eds.), Cambridge Ancient History, vol. 11, Cambridge, 1936, pp. 806-844.

Bund, E., Rahmenerwägungen zu einem Nachweis stoischer Gedanken in der römischen Jurisprudenz, in: Harder, M.; Thielmann, G. (eds.), De iustitia et iure: Festgabe für Ulrich von Lübtow zum 80. Geburtstag, Berlin, 1980, pp. 127-145.

Chambers, R. et al. (eds.), Philosophical Foundations of the Law of Unjust Enrichment, Oxford, 2009, https://doi.org/10.1093/acprof:oso/9780199567751.001.1.

Coing, H., Zum Einfluß der Philosophie des Aristoteles auf die Entwicklung des römischen Rechts, Zeitschrift der Savigny Stiftung für Rechtsgeschichte, Romanistische Abteilung, vol. 69, 1952, pp. 24-59, https://doi.org/10.7767/ zrgra.1952.69.1.24.

Colish, M. L., The Stoic Tradition from Antiquity to the Early Middle Ages I.: Stoicism in Classical Latin Literature, Leiden, 1990.

Didier, P., Les diverses conceptions du droit naturel a l'oeuvre dans la jurisprudence romaine des II'e et III' siecles, SDHI, vol. 47, 1981, pp. 195-262. 
Diesselhorst, M., Die Gerechtigkeitsdefinition Ulpians in D. 1, I, 10 pr. und die Praecepta iuris nach D. 1, 1, 10, I sowie ihre Rezeption bei Leibniz und Kant, in: Behrends, O. et al. (eds.), Römisches Recht in der europäischen Tradition. Symposion aus Anlass des 75. Geburstages von Franz Wieacker, Ebelsbach, 1985, pp. 185-212.

Frezza, P., Ius Gentium, Revue internationale des droits de l'antiquite, Mélanges Fernand de Visscher, Bruxelles, 1949, pp. 259-308.

Gallo, F., “Ars boni et aequi" e "ius naturale", SDHI, vol. 75, 2009, pp. 15-42.

Gödicke, P., Bereicherungsrecht und Dogmatik, Berlin, 2002.

Hallebeek, J., Some remarks concerning the so-called Condictio Iuventiana (D. 12, 1, 32), Revue internationale des droits de l'antiquite, 3e série, vol. 32, 1985 , pp. 247-255.

Hallebeek, J., The condiction as enrichment action in twelfth and thirteenth century legal scholarship, Tijdschrift voor Rechtsgeschiedenis, vol. 63, 1995, pp. 263-272, https://doi.org/10.1163/157181995x00130.

Harke, J. D., Vorenthaltung und Verpflichtung. Philosophische Ansichten der Austauschgerechtigkeit und ihr rechtshistorischer Hintergrund, Berlin, 2005, https://doi. org/10.3790/978-3-428-51640-7.

Harries, J., Cicero and the Jurists, London, 2006.

Harrison, A. R. W., Aristotle's Nicomachean Ethics, Book V, and the Law of Athens, The Journal of Hellenic Studies, vol. 77, no. 1, 1957, pp. 42-47.

Hausmaninger, H., "Bellum iustum" und “iusta causa belli” im älteren römischen Recht, Österreichische Zeitschrift für öffentliches Recht, vol. 9, no. 3-4, 1961, pp. 335-345.

Held, H.-R., Podrijetlo postupka legis actio per condictionem, Zbornik Pravnog fakulteta u Zagrebu, vol. 67, no. 2, 2017, pp. 197-227.

Honoré, T., Gaius, Oxford, 1962.

Honoré, T., Ulpian. Pioneer of Human Rights, Oxford, 2002, https:/doi.org/10.1093/ acprof:oso/9780199244249.001.0001.

Jong, H. de, A Byzantine interpretation of D. 12,1,32 and similar Digest fragments, Tijdschrift voor Rechtsgeschiedenis, vol. 80, 2012, pp. 47-76, https://doi. org/10.1163/157181912X626911.

Kaser, M., Das römische Privatrecht I (das altrömische, das vorklassische und klassische Recht), München, 1971.

Kaser, M., Das römische Privatrecht II (die nachklassischen Entwicklungen), München, 1975. 
Kaser, M.; Hackl, K., Das römische Zivilprozessrecht, München, 1996.

Kipp, T., Aequitas, in: Wissowa, G. (ed.), Paulys Real-Encyklopädie der classischen Altertumswissenschaft, vol. I, Stuttgart, 1894.

Klarić, P.; Vedriš, M., Građansko pravo, Zagreb, 2006.

Klimchuk, D., Unjust Enrichment and Corrective Justice, in: Neyers, J. W. et al. (eds.), Understanding Unjust Enrichment, Oxford, 2004, pp. 111-137, https:// doi.org/10.5040/9781472559562.ch-006.

Klimchuk, D., The Structure and Content of the Right to Restitution for Unjust Enrichment, University of Toronto Law Journal, vol. 57, no. 3, 2007, pp. 661-684, https://doi.org/10.1353/tlj.2007.0028.

Koschembahr-Łyskowski, I., Naturalis ratio en droit classique romain, in: Studi in onore di Pietro Bonfante, vol. III, 1930, pp. 467-498.

Kroger, J. R., The Philosophical Foundations of Roman Law: Aristotle, the Stoics, and Roman Theories of Natural Law, Wisconsin Law Review, 2004, pp. 905-944.

Kunkel, W., Herkunft und soziale Stellung der römischen Juristen, Weimar, 1952.

Kupisch, B., Ungerechtfertigte Bereicherung. Geschichtliche Entwicklungen, Heidelberg, 1987.

Lee, H. D. P., The Legal Background of Two Passages in the Nicomachean Ethics, The Classical Quarterly, vol. 31, no. 3-4, 1937, pp. 129-140, https://doi.org/10.1017/ s0009838800020528.

Lenel, O., Palingenesia iuris civilis I, Leipzig, 1889.

Lenel, O., Palingenesia iuris civilis II, Leipzig, 1889.

Levy, E., Natural Law in Roman Thought, Studia et documenta historiae et iuris, vol. 15, 1949, pp. 1-24.

Liddell, H. G. et al., A Greek-English Lexicon, Oxford, 1940. Available at: http:// www.perseus.tufts.edu (last accessed in April 2019).

Manthe, U., Beiträge zur Entwicklung des antiken Gerechtigkeitsbegriffes I: Die Mathematisierung durch Pythagoras und Aristoteles, Zeitschrift der Savigny Stiftung für Rechtsgeschichte, Romanistische Abteilung, vol. 113, 1996, pp. 1-31, https:/ doi.org/10.7767/zrgra.1996.113.1.1.

Maschi, C. A., Il diritto naturale come ordinamento giuridico inferiore?, in: L'Europa e il diritto romano. Studi in onore di Paolo Koschaker, vol. II, Milano, 1954, pp. 425-437.

Mayer-Maly, T., Privatautonomie und Vertragsethik im Digestenrecht, IVRA, vol. 6, 1955, pp. 128-138.

Mayer-Maly, T., Vom Rechtsbegriff der Römer, Österreichische Zeitschrift für öffentliches Recht, vol. 9, no. 2, 1958, pp. 151-173. 
Mayer-Maly, T., Aequitas evidens, in: Becker, W. G.; Carolsfeld, L. S. von (eds.), Sein und Werden im Recht. Festgabe für Ulrich von Lübtow zum 70. Geburtstag am 21. August 1970, Berlin, 1970, pp. 339-352.

Mayer-Maly, T., Das ius gentium bei den späteren Klassikern, IVRA, vol. 34, 1983, pp. 91-102.

Miller, W. (ed.), Cicero, De officiis, London, 1913.

Petrak, M., Plato and Ulpian's praecepta iuris, Fundamina, vol. 20, no. 2, 2014, pp. 694-701.

Pohlenz, M., Die Stoa. Geschichte einer geistigen Bewegung, Göttingen, 1948.

Powell, J.; Paterson, J. (eds.), Cicero the Advocate, Oxford, 2004, https://doi. org/10.1093/acprof:oso/9780198152804.001.0001.

Pringsheim, F., Aequitas und bona fides, in: Gesammelte Abhandlungen, Heidelberg, 1961, pp. 154-172 (= Conferenze per il XIV Centenario delle Pandette (15 Dicembre 530-15 Dicembre 1930), Pubbl. dell'Università Cattolica del Sacro Cuore, 1931., pp. 183-214).

Pringsheim, F., Bonum et aequum, in: Gesammelte Abhandlungen, Heidelberg, 1961, pp. 173-223 (= Zeitschrift der Savigny Stiftung für Rechtsgeschichte, Romanistische Abteilung, vol. 52, 1932, pp. 78-155, https://doi.org/10.7767/ zrgra.1932.52.1.78).

Pringsheim, F., Jus aequum und jus strictum, in: Gesammelte Abhandlungen, Heidelberg, 1961, pp. 131-153 (= Zeitschrift der Savigny Stiftung für Rechtsgeschichte, Romanistische Abteilung, vol. 42, 1921, pp. 643-668, https://doi. org/10.7767/zrgra.1921.42.1.643).

Pringsheim, F., Römische aequitas der christlichen Kaiser, in: Gesammelte Abhandlungen, Heidelberg, 1961, pp. 224-246 (= Acta congressus iuridici internationalis, vol. I, Rim, 1934, pp. 119-152).

Rackham, H. (ed.), Cicero, De finibus bonorum et malorum, Cambridge, 1931.

Ranieri, F., Europäisches Obligationenrecht, Wien, 2009, https://doi.org/10.1007/9783-211-89374-6.

Reeve, C. D. C. (ed.), Aristotle, Nicomachean Ethics, Cambridge, 2014.

Ross, D.; Brown, L. (eds.), Aristotle, The Nicomachean Ethics, Oxford, 2009.

Riccobono, S., Cristianesimo e diritto privato, Rivista di diritto civile, vol. 3, 1911, pp. 37-70.

Sanfilippo, C., Condictio indebiti I: Il fondamento dell'obbligazione da indebito, Milano, 1943.

Schulz, F., Die actiones in id quod pervenit und in quantum locupletior factus est (inaugural Dissertation), Borna, 1905. 
Schulz, F., History of Roman Legal Science, Oxford, 1946.

Schwarz, F., Die Grundlage der condictio im klassischen römischen Recht, Münster, 1952.

Sokolowski, P. von, Der Gerechtigkeitsbegriff des römischen Rechtes, in: Studi in onore di Pietro Bonfante, vol. 1, Milano, 1930, pp. 183-200.

Stagl, J. F., Die Ausgleichung von Vorteil und Nachteil als Inhalt klassischer aequitas, in: Mantovani, D.; Schiavone, A. (eds.), Testi e problemi del giusnaturalismo romano, Pavia, 2007, pp. 675-713.

Vander Waerdt, P. A., Philosophical Influence on Roman Jurisprudence? The Case of Stoicism and Natural Law, in: Haase, W. (ed.), Aufstieg und Niedergang der römischen Welt, vol. 36, 7 (Philosophie, Wissenschaften, Technik. Philosophie), Berlin, 1994, pp. 4851-4900, https://doi.org/10.1515/9783110883732-010.

Voigt, M., Das jus naturale, aequum et bonum und jus gentium der Römer II: das jus civile und jus gentium bei Römer, Leipzig, 1858.

Voigt, M., Römische Rechtsgeschichte II, Leipzig, 1899.

Vojković, L., Kondikcijski tužbeni zahtjevi (unpublished thesis), Split, 1997.

Waldstein, W., Aequitas und summum ius, in: Slapnicar, K. (ed.), Tradition und Fortentwicklung im Recht. Festschrift zum 90. Geburtstag von Ulrich von Lübtow am 21. August 1990, Rheinfelden, 1991, pp. 23-33.

Waldstein, W., Bemerkungen zum ius naturale bei den klassischen juristen, Zeitschrift der Savigny Stiftung für Rechtsgeschichte, Romanistische Abteilung, vol. 105, 1988, pp. 702-711, https://doi.org/10.7767/zrgra.1988.105.1.702.

Watson, A. (ed.), The Digest of Justinian I-IV (English language translation), Philadelphia, 1985.

Wollschläger, C., Das stoische Bereicherungsverbot in der römischen Rechtswissenschaft, in: Behrends, O. et al. (eds.), Römisches Recht in der europäischen Tradition. Symposion aus Anlass des 75. Geburstages von Franz Wieacker, Ebelsbach, 1985, pp. 41-88.

Zimmerman, R., The Law of Obligations. Roman Foundations of the Civilian Tradition, Cape Town, 1992.

Zuckert, M., "Bringing Philosophy down from the Heavens": Natural Right in the Roman Law, The Review of Politics, vol. 51, no. 1, 1989, pp. 70-85, https://doi. org/10.1017/s0034670500015862.

Zulueta, F. de, The Development of Law under the Republic, in: Cook, S. A. et al. (eds.), Cambridge Ancient History, vol. 9, Cambridge, 1932, pp. 842-881. 


\section{Sažetak}

\section{Doc. dr. sc. Henrik-Riko Held *}

\section{FILOZOFSKI OKVIR KONDIKCIJSKIH ZAHTJEVA U KLASIČNOM RIMSKOM PRAVU **}

Autor u radu analizira problem filozofskog okvira kondikcijskih zahtjeva u klasičnom rimskom pravu uzimajući u obzir tri različita aspekta navedene problematike. Najprije se bavi pitanjem klasičnosti određenih filozofskih načela i koncepata povezivih s kondikcijskim zahtjevima u izvorima, kao što su ius naturale, aequitas, natura itd. Ustanovivši njihovo klasično podrijetlo kao najvjerojatnije, nadalje analizira mogući utjecaj određenih konkretnih grčkih filozofskih škola. Odbacujući na temelju različitih razloga mogućnost utjecaja aristotelovskog i peripatetičkog koncepta ispravljačke pravednosti (iustitia commutativa ili correctiva) na kondikcijske zahtjeve, odlučuje se za vjerojatniji utjecaj stoičke filozofije $i$ etike, konkretno stoičke zabrane obogaćenja na teret druge osobe te opće stoičke terminologije i filozofema. Naposljetku, raspravljajući o konkretnom dosegu navedenog utjecaja, zaključuje kako je glavna uloga stoičkih načela bila potvrditi već postojeće i tipično rimsko pravno načelo utjelovljeno u primjeni legisakcije per condictionem, koje se naknadno očitovalo u raznovrsnoj upotrebi različitih kondikcijskih zahtjeva u klasičnom rimskom pravu.

Ključne riječi: condictio, stjecanje bez osnove, ius naturale, aequitas, rimsko pravo

* Dr. sc. Henrik-Riko Held, docent Pravnog fakulteta Sveučilišta u Zagrebu, Trg Republike Hrvatske 14, Zagreb; hheld@pravo.hr;

ORCID ID: orcid.org/0000-0002-6217-2655

** Ovaj članak je rezultat znanstvenog projekta Pravnog fakulteta Sveučilišta u Zagrebu naslovljenog Novi hrvatski pravni sustav za 2018. 
